\title{
Dynamic DNA methylation change in the CPG island region of $p 15$ during human myeloid development
}

\author{
Kazuo Sakashita, ${ }^{1}$ Kenichi Koike, ${ }^{1,2}$ Tatsuya Kinoshita, ${ }^{1}$ Masaaki Shiohara, ${ }^{1}$ \\ Takehiko Kamijo, ${ }^{1}$ Shun'ichiro Taniguchi, ${ }^{3}$ and Takeo Kubota ${ }^{4}$ \\ ${ }^{1}$ Department of Pediatrics, \\ ${ }^{2}$ Institute of Organ Transplants, Reconstructive Medicine and Tissue Engineering, \\ ${ }^{3}$ Department of Molecular Oncology and Angiology, Research Center on Aging and Adaptation, and \\ ${ }^{4}$ Department of Clinical and Molecular Genetics, Shinshu University School of Medicine, Matsumoto, Japan \\ Address correspondence to: Kenichi Koike, Department of Pediatrics, \\ Shinshu University School of Medicine, 3-1-1, Asahi, Matsumoto, 390-8621, Japan. \\ Phone: 81-263-37-2642; Fax: 81-263-37-3089; E-mail: koikeken@hsp.md.shinshu-u.ac.jp.
}

Received for publication April 13, 2001, and accepted in revised form September 4, 2001.

We examined the kenetics of $p 15$ methylation and expression during myeloid development. We treated human cord blood $\mathrm{CD} 34^{+}$cells with either GM-CSF alone or in combination with stem cell factor and followed methylation at this locus using bisulfite genomic sequencing. CD34 $4^{+}$cells were found to be either fully methylated or completely unmethylated at $27 \mathrm{CpG}$ dinucleotide sites in exon 1 and at $18 \mathrm{CpG}$ sites in the promoter region of the $p 15$ gene. A time-course study showed that the percentage of the allelic methylation of $p 15 \mathrm{CpG}$ island increased to approximately $50 \%$ to $60 \%$ until 7 days after cytokine stimulation, then decreased to less than $10 \%$ after 21 days. The methylation was also observed in bone marrow CD34+ cells exposed to GM-CSF. p15 expression varied inversely with methylation. Expression was negligible or at low levels until 14 days, after which it increased substantially. The frequency of myeloid colony-forming cells in the progeny decreased and myeloid-specific markers increased in the later stages. Based on our observations on cells grown with GM-CSF and 5-aza-2'-deoxycytidine, DNA methylation of the $p 15$ promoter region CpG island appears to be associated with proliferation rather than differentiation of normal human myeloid progenitors.

J. Clin. Invest. 108:1195-1204 (2001). DOI:10.1172/JCI200113030.

\section{Introduction}

p15 (also known as INK4b or MTS2) is a candidate tumor suppressor with structural and functional similarity to p16. The $p 15$ gene is located on chromosome $9 \mathrm{p} 21$, and its product is present in lymphocytes, granulocytes, and monocytes $(1,2)$. Both $\mathrm{p} 15$ and p16 specifically inhibit cyclin-dependent kinase 4 (CDK4) and CDK6 $(3,4)$, key regulators of the progression of eukaryotic cells through the G1 phase of the cell cycle. In $\mathrm{T}$ lymphocytes, $\mathrm{p} 15$ is downmodulated following stimulation with IL-2 (1). On the other hand, treatment with TGF- $\beta$ upregulates $\mathrm{p} 15$ expression in human keratinocytes, indicating that $\mathrm{p} 15$ acts as an effector of TGF- $\beta$-mediated cell cycle arrest (3).

DNA methylation is the most common eukaryotic DNA modification and one of many epigenetic phenomena. This reaction occurs at cytosine residues including CpG dinucleotides. With the exception of islands in genes on the inactive $\mathrm{X}$ chromosome and some imprinted genes, $\mathrm{CpG}$ islands are usually unmethylated in normal somatic cells $(5,6)$. Recently, it was demonstrated that inactivation of the $p 15$ gene by methylation of its $5^{\prime} \mathrm{CPG}$ island and resulting transcription block occur in some gliomas and hematologic malignancies, such as acute myelogenous leukemia (AML) and myelodysplastic syndrome (MDS) (7-9). However, it remains unclear whether methylation of the $p 15 \mathrm{CpG}$ sites occurs during normal hematopoiesis.
In the present study, the kinetics of $p 15$ methylation and expression were examined during the cytokinedependent differentiation into granulocytes and macrophages from normal hematopoietic progenitors. Here we document, we believe for the first time, a dynamic change in methylation at the $p 15 \mathrm{CpG}$ island and the inverse expression of $\mathrm{p} 15$ during myeloid development.

\section{Methods}

Factors, $A b$ 's, and reagent. Human recombinant GM-CSF, stem cell factor (SCF), and G-CSF were kindly provided by Kirin Brewery Co. Ltd. (Takasaki, Japan). For the flow cytometric analysis, the mAbs for CD34 (8G12, FITC) and $\mathrm{CD} 14[\mathrm{M} \phi \mathrm{P}$ 9, phycoerythrin (PE)] were purchased from Becton Dickinson Immunocytometry Systems (Mountain View, California, USA), and the mAbs for CD15 (80H5, FITC), CD33 (D3HL60.251, PC5), and CD34 (Immu133, PC5) were from Immunotech S.A. (Marseilles, France). The mAb against p15 (PCS-114) was obtained from NeoMarkers Inc. (Fremont, California, USA).

For the immunocytochemical analysis, purified mAbs for human CD2 (T11), CD41 (P2), and c-kit (95C3) were purchased from Immunotech. The mAbs for CD19 (HD37) and glycophorin A (JC159; GPA) were from DAKO A/S (Glostrup, Denmark). The 5-aza2'-deoxycytidine (5-Aza-CdR) was obtained from Sigma Chemical Co. (St. Louis, Missouri, USA). 
Cell preparation. Cord blood samples were aspirated in heparinized plastic syringes from the umbilical vein at normal delivery. Informed consent was obtained from the mothers of all neonates before the harvesting of specimens. Bone marrow cells were aspirated from normal volunteers. Mononuclear cells (MNCs) were separated by density centrifugation over Ficoll-Paque (Amersham Pharmacia Biotech, Uppsala, Sweden), washed twice, and suspended in $\mathrm{Ca}^{2+}$ - and $\mathrm{Mg}^{2+}$-free PBS containing 1 $\mathrm{mmol} / 1$ EDTA-2Na and 2.5\% FBS (HyClone Laboratories, Logan, Utah, USA). After treatment with Silica (Immuno-Biological Laboratories, Fujioka, Japan) for 30 minutes at $37^{\circ} \mathrm{C}, \mathrm{CD} 34$-positive cells were enriched using a Dynal CD34 Progenitor Cell Selection System (Dynal ASA, Oslo, Norway). Briefly, 2 to $4 \times 10^{7}$ cells were mixed with the same number of polystyrene beads coated with a mAb specific for CD34 (Dynabeads M-450 CD34) and incubated for 30 minutes at $4^{\circ} \mathrm{C}$. Bead-rosetted cells were separated by a magnet. For the detachment of the beads from the cells, affinity-purified polyclonal Ab's against the Fab portion of anti-CD34 Ab (Detach-a-Bead CD34) were added, and incubation was carried out for $45 \mathrm{~min}$ utes at room temperature. The detached beads were removed by the magnet, and the cells were collected as $\mathrm{CD}^{2} 4^{+}$cells. More than $90 \%$ of the isolated cells were CD34 positive, as determined by FACScan flow cytometry (Becton Dickinson Immunocytometry Systems).

Isolation of cord blood CD34+ $4^{+}$cells or day 5-cultured cells (CD14-CD $15^{-}$cells and $\mathrm{CD} 14^{+} \mathrm{CD} 15^{+}$cells) was also performed with a FACStarplus flow cytometer, as described previously (10-12).

Suspension cultures. Twenty thousand CD34+ cells were cultured in each well of 24-well culture plates (\#3047; Becton Dickinson Immunocytometry Systems) containing $2 \mathrm{ml}$ of $\alpha$-medium (ICN Biomedical Inc., Aurora, Ohio, USA) supplemented with $1 \%$ deionized BSA (Sigma Chemical Co.), $10 \%$ FBS, and $10 \mathrm{ng} / \mathrm{ml}$ of GM-CSF and/or $10 \mathrm{ng} / \mathrm{ml}$ of SCF. The plates were incubated at $37^{\circ} \mathrm{C}$ in a humidified atmosphere flushed with $5 \% \mathrm{CO}_{2}$ in air. Half of the culture medium was replaced weekly with fresh medium containing the factor(s). The number of viable cells was determined by a trypan-blue exclusion test using a hemocytometer on days $7,14,21$, and 28 . We presented the actual counts of progeny in the results.

Clonal cell culture. Clonal cell cultures were carried out in 35-mm Lux suspension culture dishes (\#171099; Nalge Nunc International, Naperville, Illinois, USA) by a technique described previously (10). The culture consisted of 1,000 cells $/ \mathrm{mL}, \alpha$-medium, $0.9 \%$ methylcellulose (Shin-Etsu Chemical Co. Ltd., Tokyo, Japan), 1\% deionized BSA, 30\% FBS, and $10 \mathrm{ng} / \mathrm{ml}$ of GM-CSF with or without $10 \mathrm{ng} / \mathrm{ml}$ of SCF. Dishes were incubated at $37^{\circ} \mathrm{C}$ in a humidified atmosphere flushed with $5 \% \mathrm{CO}_{2}$. On day 14 , granulocyte-macrophage (GM) colonies consisting of 20 constituent cells were scored in situ on an inverted microscope.

The size of GM colonies ( $<500$ cells) was determined by direct cell counting in situ under an inverted microscope at a magnification of $\times 150$, as described previ- ously (13). Colonies consisting of $>500$ cells were individually lifted with an Eppendorf micropipette and prepared as single cell suspensions. The colony size was estimated by using a counting chamber.

Flow cytometric analysis. For the analysis of surface markers on the cultured cells, 1 to $2 \times 10^{5}$ cells were collected in plastic tubes and incubated with a combination of an appropriately diluted PE-conjugated anti$\mathrm{CD} 14 \mathrm{mAb}$ and FITC-conjugated anti-CD15 $\mathrm{mAb}$, as described previously $(13,14)$ After the cells were washed twice, their surface markers were analyzed with a FACScan flow cytometer using the Lysis 2 software program. Viable cells were gated according to their forward light-scatter characteristics (FSC) and side-scatter characteristics (SSC). The proportion of positive cells was determined by comparison with cells stained with PE- and FITC-conjugated mouse isotype-matched IgG (DAKO A/S). The expression of CD34 and CD33 on day 8 -cultured cells (CD14-/CD15- cells and $\mathrm{CD} 14^{+} / \mathrm{CD} 15^{+}$cells) grown with GM-CSF was analyzed, using PC5-conjugated anti-CD34 mAb or antiCD33 mAb, as described previously (11).

For assaying the intracellular p 15 expression of leukemic cell lines, cord blood $\mathrm{CD} 34^{+}$cells and the cultured cells generated with GM-CSF or GM-CSF + SCF, the cells were fixed and subsequently permeabilized, using Dako IntraStain (DAKO A/S), as described previously (15). The cells were incubated with $5 \mu \mathrm{l}$ of antip $15 \mathrm{mAb}$ for 30 minutes at room temperature. Mouse IgG1 was used as a control. The cells were washed three times and stained with biotinylated goat anti-mouse immunoglobulin (Becton Dickinson Immunocytometry Systems) for 15 minutes. After three washes, the cells were stained with PE-conjugated streptavidin (Life Technologies Inc., Gaithersburg, Maryland, USA). In the case of $\mathrm{CD} 34^{+}$cells, cord blood MNCs were stained with anti-p $15 \mathrm{mAb}$ and then treated with mouse serum for 15 minutes at $4^{\circ} \mathrm{C}$, followed by labeling with FITCconjugated anti-CD34 mAb. Data are expressed as the relative fluorescence intensity (RFI), as described previously (16): RFI [mean fluorescence intensity of cells stained with anti-p15 mAb] $\div$ [mean fluorescence intensity of cells stained with control mouse IgG1].

For the analysis of cellular apoptosis, we carried out a flow cytometric analysis using propidium iodide (PI; Sigma Chemical Co.), according to the procedure described previously (17).

Cytochemical staining. Cultured cells $\left(5 \times 10^{3}\right)$ were spread on glass slides using a Cytospin II (Shandon Inc., Pittsburgh, Pennsylvania, USA) and stained with May-Grünwald-Giemsa, $\alpha$-naphthyl butyrate esterase (ANB), or naphthol AS-D chloroacetate esterase (NASDCA), as described previously (13).

Immunocytochemical staining. Reactions with mouse mAbs against CD2, CD19, CD41, GPA, and c-kit were detected using the alkaline phosphatase-anti-alkaline phosphatase method (Dako APAAP Kit System; Dako Corp., Carpinteria, California, USA), as described previously (18). We used the isotype mouse mAb as a control. 
Table 1

Primer sequences

\begin{tabular}{|c|c|c|}
\hline Primer & Sequence & Position \\
\hline $\mathrm{p} 15-\mathrm{F}$ & 5'-GGTTGGTITITATITTGTTAGAG-'3 & $-12 /+12$ \\
\hline p15-R & 5'-ССТТСТАAAAAACCТАAАСТСАA-'3 & $+228 /+251$ \\
\hline p15-PF & 5'-TGGGGATTAGGAGTTGAGGG-'3 & $-285 /-266$ \\
\hline P15-PR & $5^{\prime}$-СТCTAACAAAATAAAAAACCAACC-'3 & $-12 /+12$ \\
\hline p15-MF & 5'-GCGTTCGTATITTGCGGTT-'3 & $+41 /+59$ \\
\hline p15-MR & 5'-CGTACAATAACCGAACGACCGA-'3 & $+166 /+187$ \\
\hline p15-UF & 5'-GTITTGAGTTTGGTTGTGTTTGT-'3 & $+66 /+88$ \\
\hline p15-UR & 5'-АТТААСТССАААСТТТТССТААСА-' 3 & $+140 /+164$ \\
\hline p16-F & 5'-GTAGGTGGGGAGGAGTTTAGTT-'3 & $-355 /-334$ \\
\hline p16-R & 5'-TCTAATAACCAACCAACСССТСС-'3 & $-95 /-73$ \\
\hline
\end{tabular}

Western blot analysis. Western blot analysis was performed, as described previously (19). The total cell lysates were subjected to $15 \%$ SDS-PAGE. The protein samples separated by SDS-PAGE gels were transferred to PVDF membranes (Immobilon; Millipore Corp., Bedford, Massachusetts, USA), identified with anti-p15 mAb (15P06; NeoMarkers Inc.), and developed by the enhanced chemiluminescence system (Amersham Pharmacia Biotech). We used anti-actin mAb (Santa Cruz Biotechnology Inc., Santa Cruz, California, USA) as a control.

Bisulfite treatment of DNA samples. DNA was extracted from leukemic cell lines, cord blood CD $34^{+}$cells sorted by flow cytometry, and the cultured cells generated by GM-CSF or GM-CSF + SCF, using standard phenol chloroform extraction with ethanol precipitation. DNA was treated with sodium bisulfite, using the CpGenome DNA Modification Kit (Oncor Inc., Gaithersburg, Maryland, USA), according to the manufacturer's instructions. Following conversion, the bisulfite-treated DNA was resuspended in a total volume of $25 \mu \mathrm{l}$ of distilled water.

Methylation-specific PCR and sequencing. A fragment of the $\mathrm{CPG}$ island region of the $p 15$ gene $(-12$ to +251 relative to the transcriptional starting point) was amplified by PCR using the primers (p15-F and $\mathrm{p} 15-\mathrm{R})$, as presented in Table 1 . The primers ( $\mathrm{p} 15-\mathrm{PF}$ and $\mathrm{p} 15-\mathrm{PR}$ ) were also constructed to amplify a region located between positions -285 and +12 relative to the transcriptional starting site. PCR was carried out in a

\section{Figure 1}

Myeloid cell production from cord blood $\mathrm{CD} 34^{+}$cells under stimulation with GM-CSF or GM-CSF + SCF. (a) Cord blood CD34 $4^{+}$cells $\left(2 \times 10^{4}\right)$ were plated in a well containing $10 \mathrm{ng} / \mathrm{ml}$ of GM-CSF with or without $10 \mathrm{ng} / \mathrm{ml}$ of SCF. The number of viable cells was serially counted every week. The time course of the relative frequency of cells positive for CD14 and/or CD15 and the relative frequency of $\mathrm{ANB}^{+}$ cells and $\mathrm{NASDCA}^{+}$cells were examined. Similar results were obtained in two other experiments. Values are expressed as the mean $\pm \mathrm{SD}$. $\mathrm{ANB}^{+}$cells (gray bars) and $\mathrm{NASDCA}^{+}$cells (white bars). (b) Expression of CD14 and CD15 on the cultured cells generated by GM-CSF or GM-CSF + SCF from cord blood CD34+ cells. Surface marker expressions were analyzed by a flow cytometer. final volume of $25 \mu \mathrm{l}$ containing $100 \mathrm{ng}$ of bisulfitetreated DNA, $20 \mathrm{mM}$ Tris- $\mathrm{HCl}$ (pH 7.5), $100 \mathrm{mM} \mathrm{KCl}$, $2 \mathrm{mM} \mathrm{MgCl}_{2}, 0.2 \mathrm{mM}$ each dNTP, $0.5 \mu \mathrm{M}$ each primer, and 0.5 units of AmpliTaq Gold (Roche Molecular Systems Inc., Branchburg, New Jersey, USA). The samples were denatured at $95^{\circ} \mathrm{C}$ for 10 minutes, then subjected to 35 cycles at $95^{\circ} \mathrm{C}$ for 30 seconds, at $57^{\circ} \mathrm{C}$ for $30 \mathrm{sec}$ onds, and at $72^{\circ} \mathrm{C}$ for 30 seconds with a final 5 minutes of extension at $72^{\circ} \mathrm{C}$ in PTC-100 Programmable Thermal Controller (MJ Research Inc., Waltham, Massachusetts, USA). Twenty-five microliters of PCR product was loaded onto a 3\% agarose gel. Then, bands were excised from the gel and purified with the Geneclean II Kit (Bio 101 Inc., Carlsbad, California, USA). The gelpurified PCR fragments were cloned into a pGEM-T Vector (Promega Corp., Madison, Wisconsin, USA), as recommended by the manufacturer. Plasmid was purified using Wizard Plus Miniprep DNA Purification Systems (Promega Corp.). Individual clones were
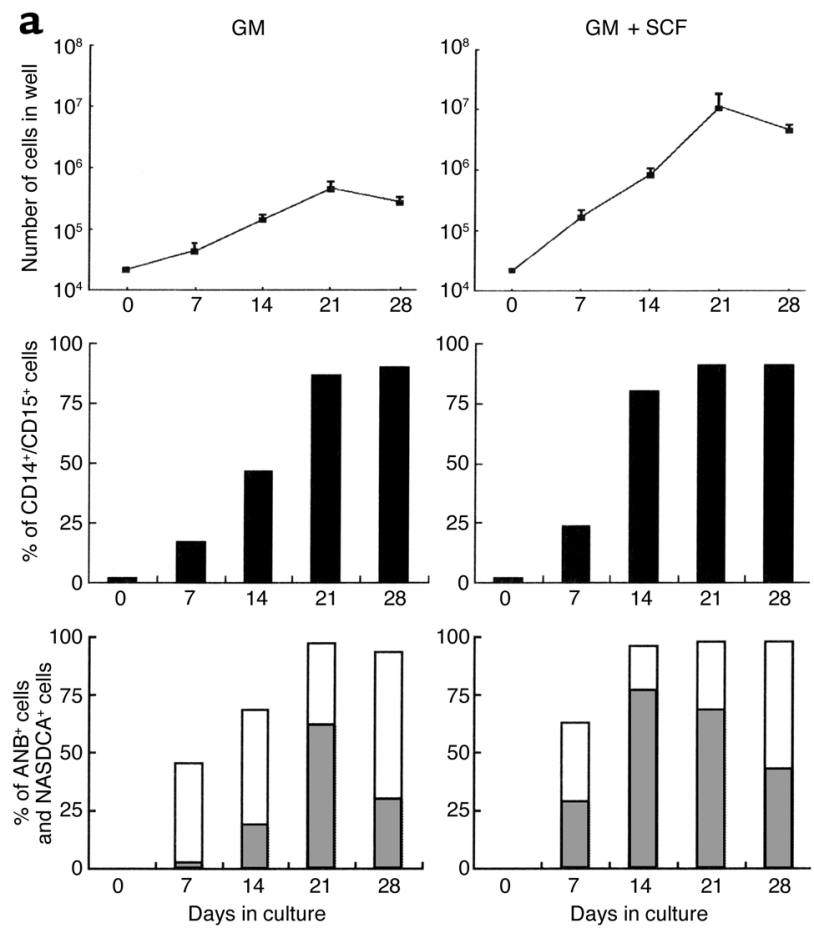

b Day 0
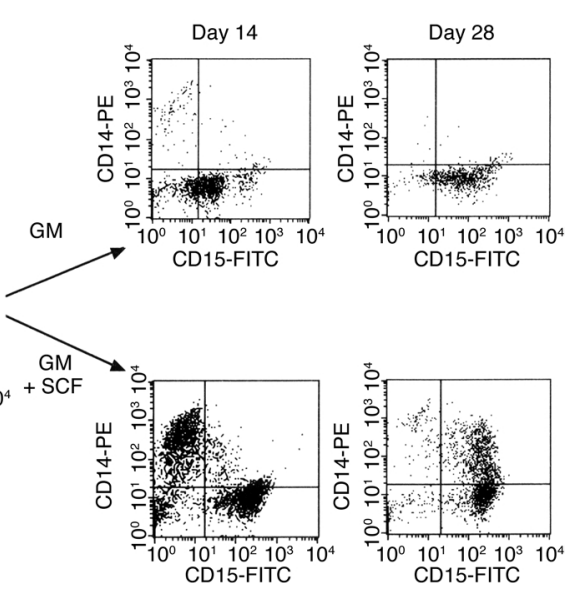

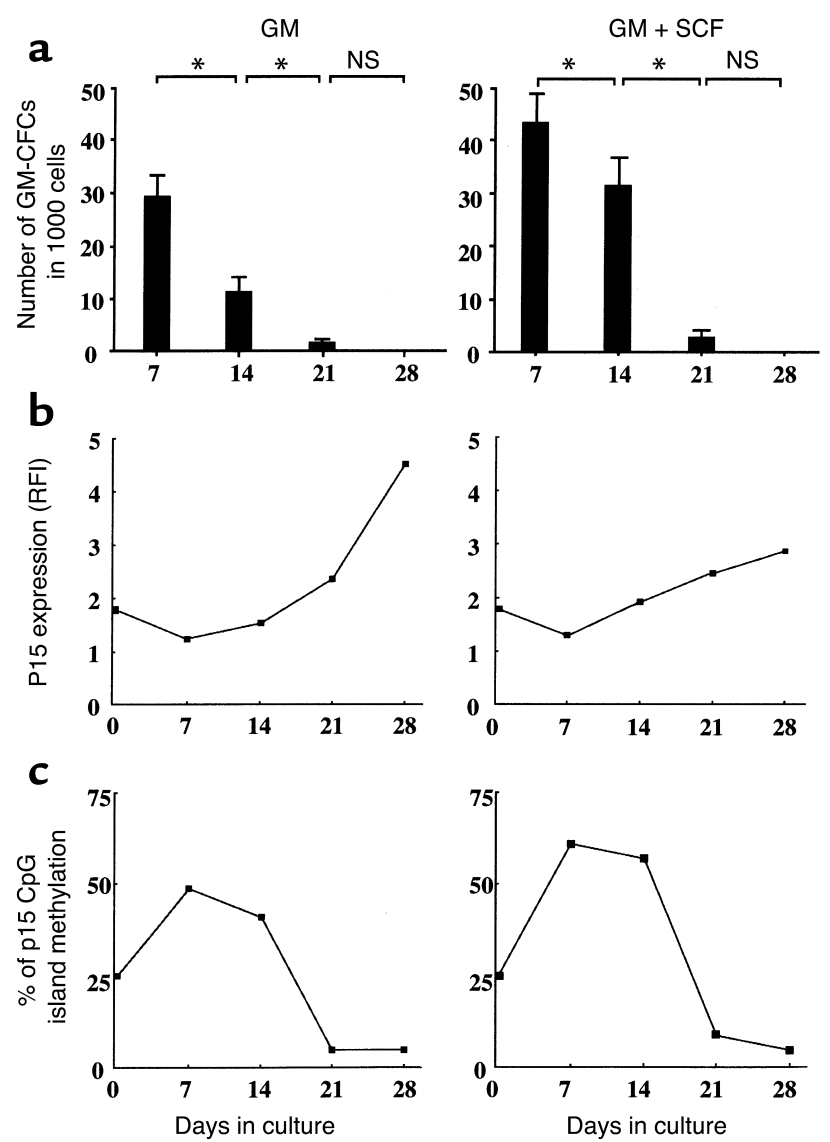

Figure 2

Time course of GM precursor number, intracellular $p 15$ expression, and methylation of the $\mathrm{P} 15 \mathrm{CpG}$ island in the cultured cells generated by GM-CSF or GM-CSF + SCF from cord blood CD34+ cells. (a) Numbers of GM colony-forming cells (GM-CFCs) in 1,000 cultured cells at various time points. The cultured cells generated by GM-CSF were plated in a dish containing methylcellulose culture medium supplemented with $10 \mathrm{ng} / \mathrm{ml}$ of GM-CSF. In the case of the cultured cells generated by GM-CSF + SCF, the incidence of GM precursors was assayed in a semisolid culture medium containing $10 \mathrm{ng} / \mathrm{ml}$ of GMCSF and $10 \mathrm{ng} / \mathrm{ml}$ of SCF. ${ }^{*}$ Significant difference between the two groups; NS, no significance. (b) Intracellular p15 expression of the cultured cells determined by flow cytometry. Data are expressed as RFI. (c) The percentage of allelic methylation in the CpG island region of $\mathrm{p} 15$. The data are the sum total of the results obtained by the sequence method and by PCR analysis.

sequenced on a Hitachi SQ-5500 (Hitachi Ltd., Tokyo, Japan) using the Thermo Sequenase pre-mixed cycle sequencing kit (Amersham International, Amersham, United Kingdom). To discriminate between methylation and unmethylation of the $\mathrm{CPG}$ island in exon 1 of the $p 15$ gene, we used two primer sets (p15-MF and $\mathrm{p} 15-\mathrm{MR}$; $\mathrm{p} 15-\mathrm{UF}$ and $\mathrm{p} 15-\mathrm{UR}$ ). The primers (p16-F and $\mathrm{p} 16-\mathrm{R})$ for amplification of the $\mathrm{p} 16$ promoter region were designed on the basis of previous reports $(20,21)$. PCR was carried out as described above.

Statistical analysis. All experiments were carried out at least two times and were shown to be reproducible. Values are expressed as means plus or minus SD. Student's $t$ test was used to determine the significance of differ- ences between two independent groups. One-way ANOVA, followed by post hoc contrasts with Bonferroni limitation, was used for three independent groups.

\section{Results}

Selective grow th of granulocytes and macrophages from cord blood CD $34^{+}$cells under stimulation with GM-CSF or GM$C S F+S C F$. We compared the ability of $10 \mathrm{ng} / \mathrm{ml}$ of GM$\mathrm{CSF}$ and/or $10 \mathrm{ng} / \mathrm{ml}$ of SCF to generate granulocytes and macrophages from cord blood CD $34^{+}$cells. The results are presented in Figure 1. Under stimulation with GM-CSF alone, the number of total viable cells increased to a maximum of 20 -fold the input quantity at day 21. The addition of SCF to the culture with GM-CSF caused a marked increment in the numbers of viable cells during the culture period. With both treatments, the cell number decreased at day 28 . This may be due in part to apoptotic death, because the frequency of subdiploid nuclei in PI-stained samples of day 28 -cultured cells was $20.3 \%$ in the presence of GM-CSF and $26.4 \%$ in the presence of GM-CSF + SCF (data not shown). When $10 \mathrm{ng} / \mathrm{ml}$ of G-CSF was added on day 21 to the culture containing GM-CSF with or without SCF, the number of total viable cells increased by $12 \%$ to $15 \%$ (data not shown). In the presence of GM-CSF alone, $39 \%$ and $11 \%$ of day 14 -cultured cells were CD14-CD $15^{+}$cells and $\mathrm{CD} 14^{+} \mathrm{CD} 15^{-}$cells, respectively. Four percent of them were positive for the two antigens. After 21 days, a large part of the progeny displayed selective expression of CD15 antigen. On the other hand, the two-factor combination hastened myeloid differentiation. A great majority of the day 21and day 28-cultured cells were positive for CD15, and one-half of them reacted with anti-CD14 mAb. Terminal differentiation into myeloid cell lineage under stimulation with GM-CSF or GM-CSF + SCF was confirmed by differential counting of the cytospin preparations stained with ANB and NASDCA. The cells with other lineage-specific markers (CD2, CD19, CD41, GPA, and c-kit) were at negligible levels after 7 days. SCF alone supported the growth of significant numbers of cells, which was comparable to the level obtained by GM-CSF alone during the culture period. On days 21 and 28 , however, only $38 \%$ to $55 \%$ of the cultured cells expressed myeloid cell antigens, and $12 \%$ to $16 \%$ of the cultured cells were positive for c-kit (data not shown). From these results, we selected GM-CSF and GM-CSF + SCF as favorable stimuli for the differentiation into the myeloid cell lineage from cord blood hematopoietic progenitors.

To assess the proliferative potential of the individual cultured cells generated by GM-CSF with or without SCF, we performed clonal cell culture experiments. The results are presented in Figure 2a. In response to both types of stimulation, there was a gradual decrease in the frequency of GM precursors with the culture period. The progeny grown after 21 days contained granulocyte-macrophage precursors at negligible or very low levels in the two groups. 


\section{Figure 3}

Intracellular p15 expression of leukemic cell lines, cord blood CD34+ cells, and the cultured cells generated by GM-CSF or GM-CSF + SCF from cord blood CD34+ cells. The cells were fixed and subsequently permeabilized. Then, the intracellular p15 expression was determined by flow cytometry. (a) Leukemic cell lines and cord blood CD $34^{+}$cells. (b) The cultured cells generated by GM-CSF or GMCSF + SCF from cord blood CD $34^{+}$cells. Solid lines indicate the cells stained with anti-p15 $\mathrm{mAb}$; the dotted lines indicate cells stained with mouse IgG1. (c) Thirty micrograms of cell lysates from cord blood CD $34^{+}$cells or cultured cells were subjected to $15 \%$ SDSPAGE, transferred to PVDF membranes, and immunoblotted with anti-p15 mAb. Actin was used as a control.

p15 expression during myeloid differentiation supported by GM-CSF or GM$C S F+S C F$. We examined changes of p15 expression in this differentiation pathway. First, we analyzed the intracellular p15 expression of several leukemic cell lines according to the cytofluorometric analysis. K562 cells were used as a negative control on the basis of homozygous deletion of the 9p21 region containing the $\mathrm{p} 15$ and $\mathrm{p} 16$. As presented in Figure 3a, there was no significant p15 positivity in K562 cells (the RFI was 1.07). In Raji cells, the RFI was 1.25. On the other hand, HL-60 cells were reactive to anti-p $15 \mathrm{mAb}$ (the RFI was 3.24). The RFI of KU812 cells was 3.81 (data not shown). These results were consistent with the evidence obtained previously (22). Cord blood CD $34^{+}$cells were weakly positive for $\mathrm{p} 15$. Under stimulation with GM-CSF or GM-CSF + SCF, $\mathrm{p} 15$ was expressed at negligible or low level in the cultured cells up to day 14, as shown in Figures 2b and $3 \mathrm{~b}$. Subsequently, intracellular p15 content increased to the level comparable to p15-positive leukemic cell lines. A time-dependent increment in $\mathrm{p} 15$ protein levels was confirmed by $15 \%$ SDS-PAGE analysis followed by Western blot analysis, as shown in Figure 3c.

Allelic methylation status of $C p G$ sites at the $p 15$ locus during myeloid differentiation supported by GM-CSF or GM-CSF + $S C F$. To elucidate the regulatory mechanism for $\mathrm{p} 15$ expression during the differentiation into granulocytes and macrophages, we first studied the methylation sta-

b

c

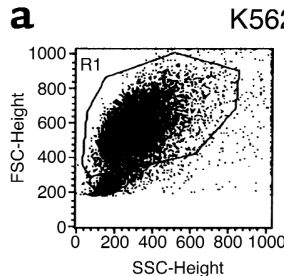

K562 Cells

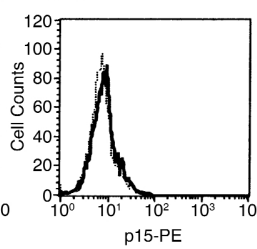

HL60 Cells
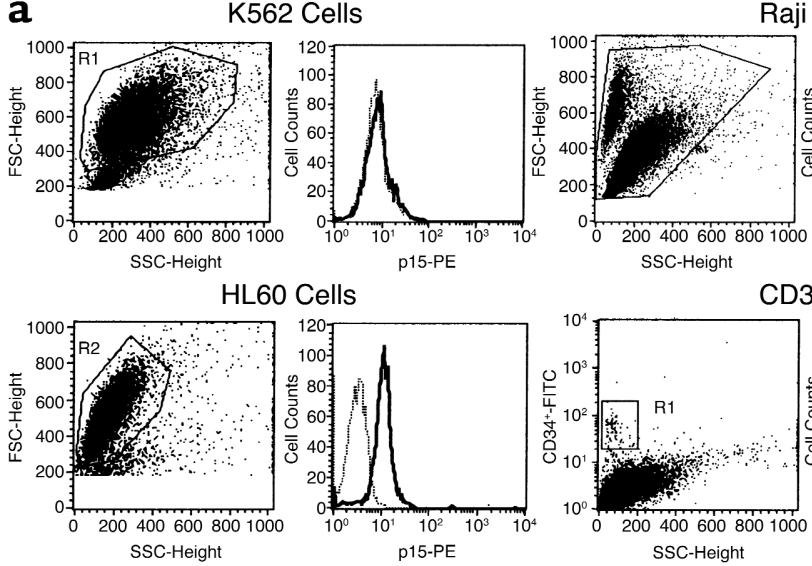

Raji Cells

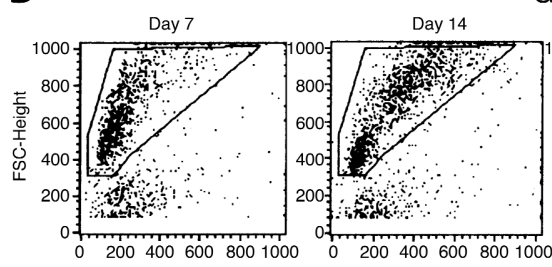

GM
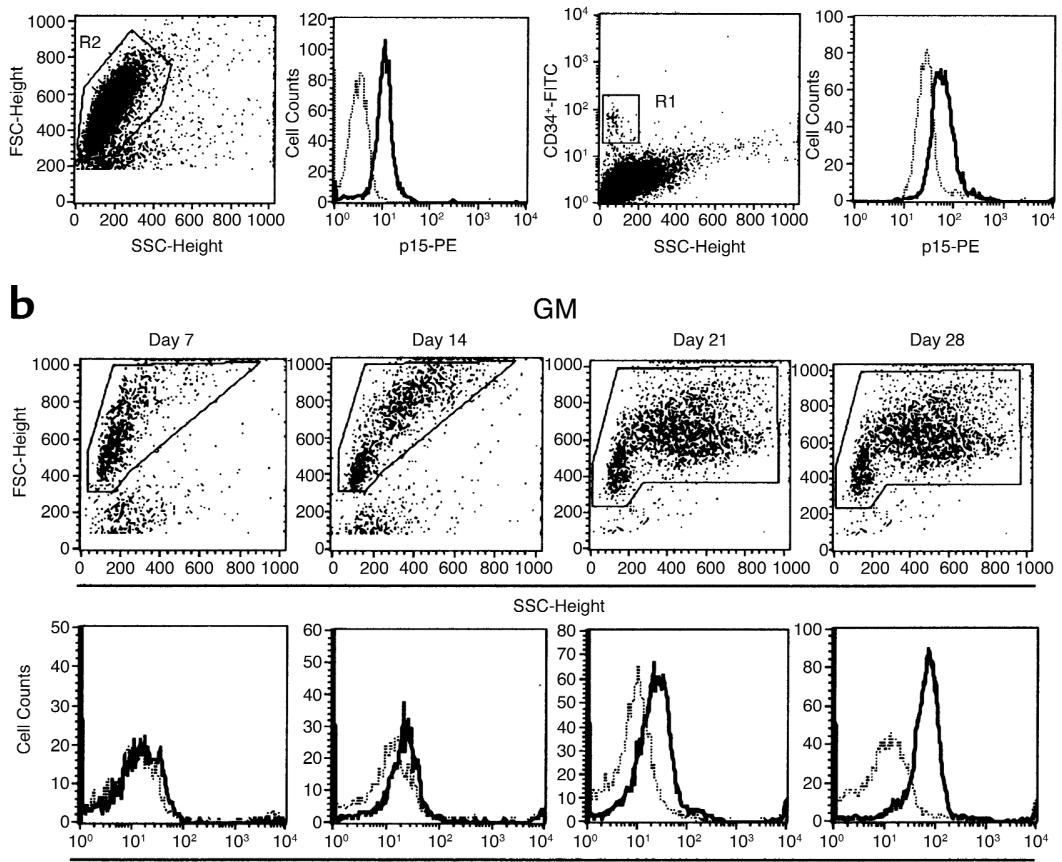

SC-Height
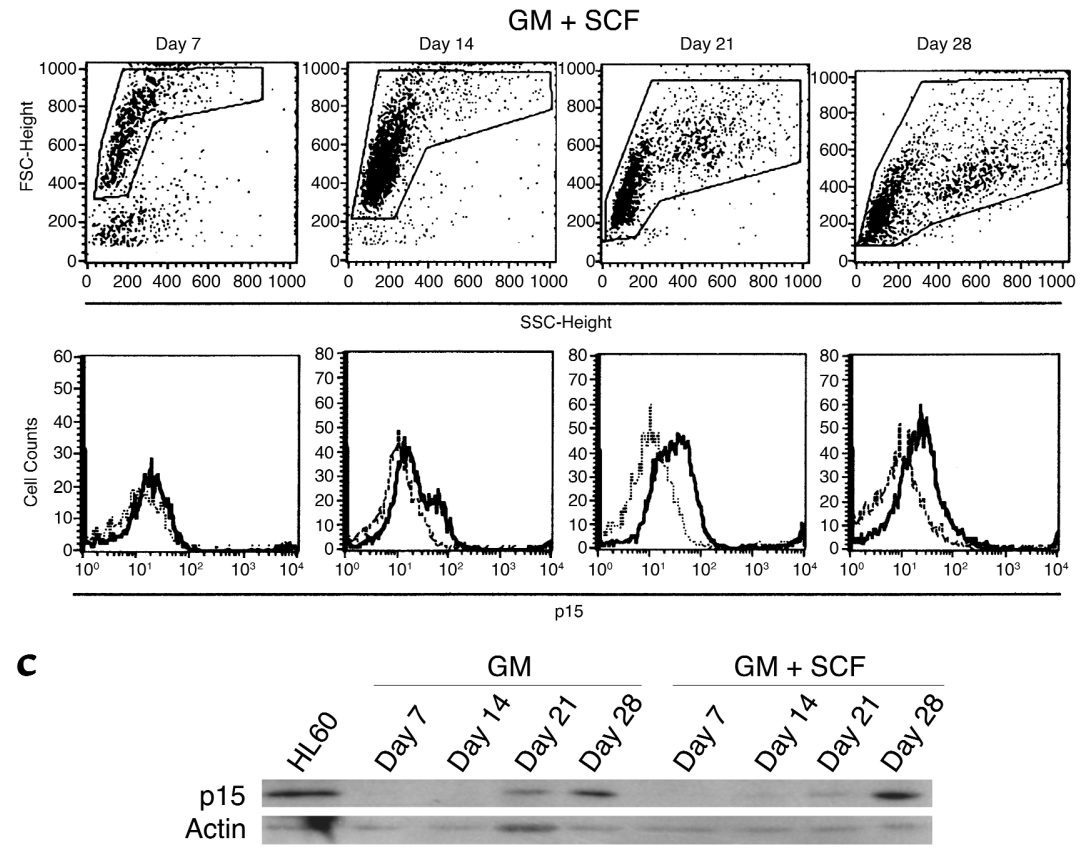

tus of each $\mathrm{CpG}$ site within the region located between positions -12 and +251 relative to the transcriptional starting site of the p15 gene, by bisulfite genomic sequencing. Hypermethylation of this sequence has been demonstrated to be associated with transcriptional silencing in AML and MDS $(9,23,24)$. As shown in Fig- 
a p15 gene

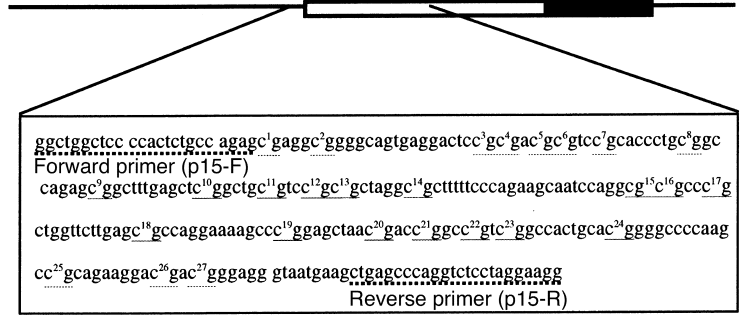

b
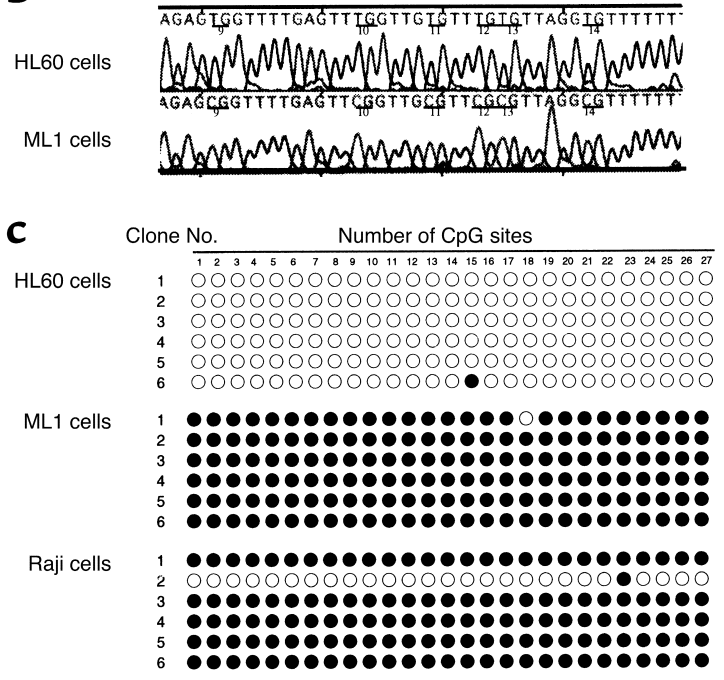

ure $4 \mathrm{a}$, the region contains $27 \mathrm{CpG}$ dinucleotides and 60 non-CpG cytosines. Primers were designed in the region without $\mathrm{CPG}$ dinucleotides to amplify both methylated and unmethylated alleles. Figure 4, b and c, show the allelic patterns of $\mathrm{CpG}$ island methylation in three leukemic cell lines. HL60 cells were nearly devoid of methylated CPG sites, whereas ML1 cells were methylated at almost all CpG sites on every allele sequenced. Most Raji cells had completely methylated alleles. In part, these results are consistent with those described by Cameron et al. (25).

We examined whether methylation occurred within this region during myeloid differentiation. As shown in Figure 5 a, approximately $20 \%$ of cord blood $\mathrm{CD} 34^{+}$cells sorted by flow cytometry were methylated at all of the 27 CpG sites within the target sequence. The cultured cells grown with GM-CSF alone were found to be either fully methylated or completely unmethylated at the $p 15$ CpG island until day 28 of culture. Similar results were obtained in the stimulation with GM-CSF + SCF. For an easy discrimination of methylated and unmethylated p15 CPG islands, we designed two sets of primers ( $\mathrm{p} 15-\mathrm{MF}$

\section{Figure 4}

Bisulfite genomic sequencing. (a) Sequence of the CpG island region of the $p 15$ gene $(-12$ to +251 relative to the transcriptional starting site). The binding sites of the primers used in this experiment are also shown ( $\mathrm{p} 15-\mathrm{F}$ and $\mathrm{p} 15-\mathrm{R}$ ). (b) Sequence analysis of HL60 cells and ML1 cells. The region encompassing the 9 th to 14 th $\mathrm{CPG}$ site is shown. In HL60 cells, all cytosines, including six CPG dinucleotides, were invariably converted to uracils by the treatment with sodium bisulfite and appeared as thymidines after PCR. On the other hand, methylated cytosines at all of six CPG sites in ML1 cells remained unreactive. (c) The allelic methylation status of the $p 15 \mathrm{CpG}$ island in various leukemic cell lines. Each row represents an individual cloned and sequenced allele following the bisulfite treatment. Methylated CpG sites are marked as filled circles and unmethylated sites as open circles. Numbers at the top correspond to those of the CPG sites shown in $\mathbf{a}$.

and p15-MR; p15UF and p15-UR, shown in Table 1). If these primers mixed together with the individual clones annealed to either the methylated or unmethylated DNA, the expected molecular size would be $147 \mathrm{bp}$ and $99 \mathrm{bp}$, respectively. As presented in Figure 6a, the result of PCR with a mixture of the four primers (p15-MF, p15-MR, p15-UF, and p15-UR) corresponded to the data obtained by the separated PCR. The accuracy of the PCR analyses was also confirmed from the results of individual alleles characterized by the sequencing, as shown in Figure 6b. The sum total of the results obtained by the sequencing method and those by the PCR analysis showed that the percentage of alleles with methylated $\mathrm{CPG}$ islands increased to $50 \%$ until day 7 and then decreased in the presence of GM-CSF alone, as shown in Figures $2 c$ and 6c. On stimulation with GM-CSF + SCF, methylation of the $15 \mathrm{CpG}$ island was maintained for up to 14 days at a modestly high level relative to the values obtained from the stimulation with GM-CSF alone. Then, the incidence of methylation declined to less than $10 \%$. Normal bone marrow cells could also be induced to methylate by GM-CSF, as shown in Figure 5b. None of ten alleles derived from marrow $\mathrm{CD} 34^{+}$cells were methylated, which was confirmed by the PCR analysis. This result was in agreement with that reported previously (26). The frequency of alleles with methylated $p 15 \mathrm{CpG}$ islands increased to $50 \%$ on day 7 under stimulation with GM-CSF and decreased on day 21. In clonal cell culture

\section{Table 2}

Physiologic role of $15 \mathrm{CpG}$ island methylation in myeloid development

\begin{tabular}{lcccc}
\hline & GM-CSF & GM-CSF + & GM-CSF + & None \\
& & 5 -Aza-CdR $\left(10^{-6} \mathrm{M}\right)$ & 5 -Aza-CdR $\left(10^{-7} \mathrm{M}\right)$ & \\
& $7.7 \pm 0.4$ & $5.5 \pm 0.2^{\mathrm{A}}$ & $6.5 \pm 0.2$ & $3.7 \pm 0.4^{\mathrm{A}}$ \\
umber of cells $\left(\times 10^{4}\right)$ & 28 & 24 & 22 & 27 \\
of CD $14^{+} / \mathrm{CD} 15^{+}$cells & 44 & 4 & 24 & 8 \\
of $15 \mathrm{CpG}$ island methylation & 0.96 & 2.18 & 1.06 & 2.07 \\
5 expression & & &
\end{tabular}

Day 5 -cultured cells $\left(4 \times 10^{4}\right)$ grown with GM-CSF from CD34+ cord blood cells were harvested and replated in the culture containing GM-CSF, GM-CSF + 5-Aza-CdR $\left(10^{-6} \mathrm{M}, 10^{-7} \mathrm{M}\right)$, or no factors. After 3 days, number of viable cells, percentage of myeloid cells, percentage of $\mathrm{p} 15 \mathrm{CpG}$ island methylation, and $\mathrm{p} 15$ expression were compared. The percentages of alleles with methylated $p 15 \mathrm{CpG}$ islands in 25 alleles were determined by the PCR analysis. The frequency of the allelic methylation in the day 5 -cultured cells was $12 \%$. Data of p15 expression are expressed as RFI. ASignificantly different from GM-CSF alone. 

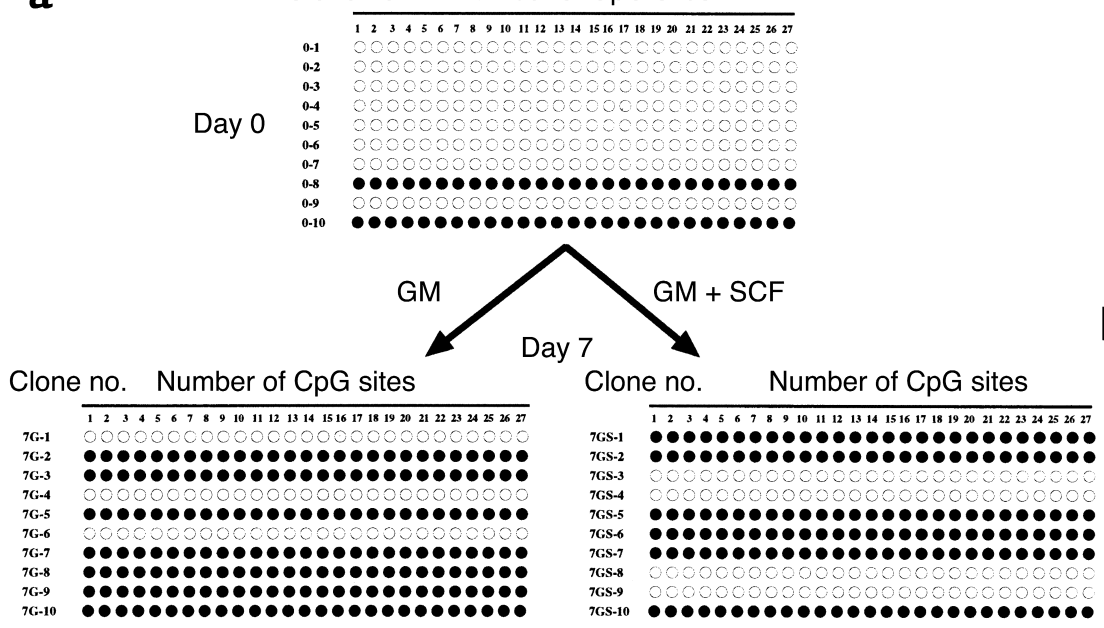

Day 14
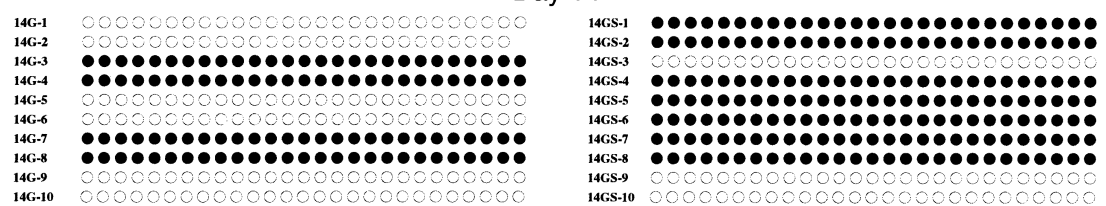

Day 21
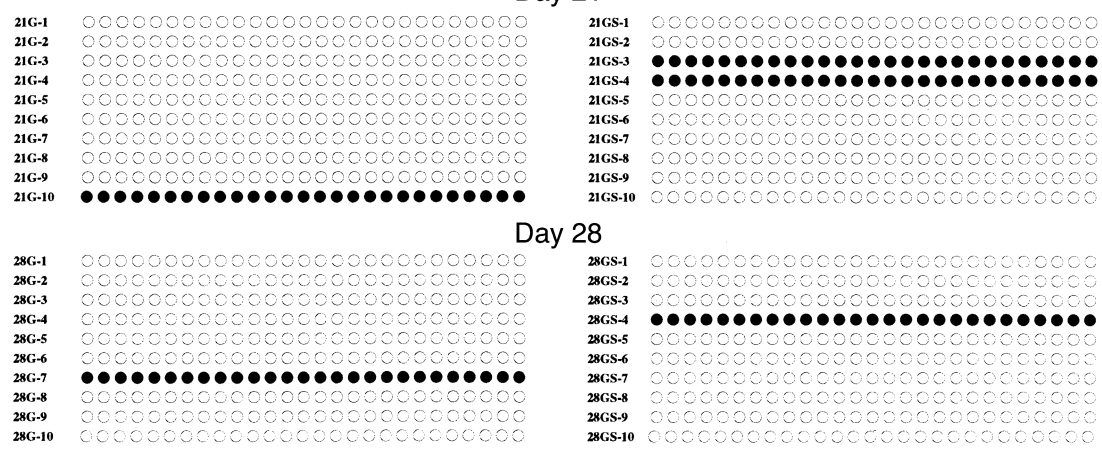

Day 28

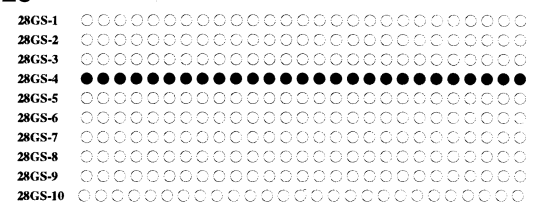

b

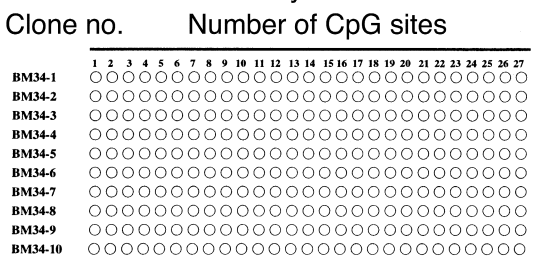

Day 7

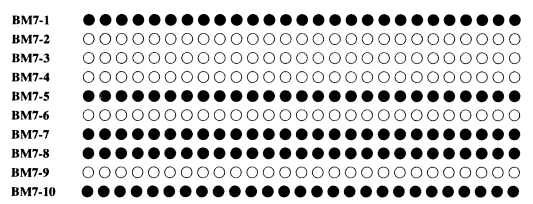

Day 21

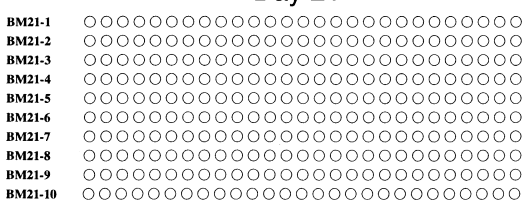

Figure 5

Allelic patterns of CpG island methylation at the $p 15$ locus during myeloid development from cord blood or bone marrow $\mathrm{CD}^{+} 4^{+}$cells. Methylation of the $\mathrm{p} 15 \mathrm{CpG}$ island located between positions -12 and +251 relative to the transcriptional starting site was examined by bisulfite genomic sequencing. Methylated CPG sites are marked as filled circles and unmethylated sites as open circles. Numbers at the top correspond to those of the $\mathrm{CPG}$ sites shown in Figure $4 \mathrm{a}$. Each row of circles corresponds to one clone. (a) Cord blood CD34+ cells were stimulated with GM-CSF or GM-CSF+SCF. (b) Normal bone marrow CD34+ cells were stimulated with GM-CSF.

experiments of bone marrow $\mathrm{CD} 34^{+}$cells with GM-CSF, methylation data emerged in all ten 10-day GM colonies, ranging from $10 \%$ to $60 \%(38 \% \pm 23 \%)$.

Next, we attempted to elucidate the methylation status of the $\mathrm{CPG}$ dinucleotides in the promoter region $(-285$ and +12 relative to the transcriptional starting point) of the $p 15$ gene during GM-CSF-dependent myeloid differentiation. The region is known to contain some trans-acting factor binding sites. As presented in Figure 7, there was a dynamic change of methylation in the promoter region examined. All of $18 \mathrm{CpG}$ sites in the promoter region were either methylated or unmethylated in individual alleles. Although we failed to determine whether allelic methylation in the promoter region synchronized with that in exon 1 at the p15 locus because of a technical difficulty, allelic methylation pattern was similar between the two regions.
Physiologic role of $p 15$ CPG island methylation in myeloid development. Finally, we examined a role of an initial increase in CPG island methylation of the $p 15$ gene in normal myeloid development. Forty thousand day 5-cultured cells grown with GM-CSF from cord blood $\mathrm{CD} 34^{+}$cells were incubated in wells containing GM-CSF with or without 5-Aza-CdR for 3 days. The frequency of alleles with methylated $\mathrm{CpG}$ islands was $12 \%$ on day 5 and increased to $44 \%$ on day 8 in the presence of GM-CSF, as presented in Table 2. The addition of 5-Aza$\mathrm{CdR}$ at $10^{-6} \mathrm{M}$ canceled the GM-CSF-mediated increment of $\mathrm{CPG}$ island methylation, associated with an increased expression of the gene. The mean number of total viable cells was significantly lower in the culture containing GM-CSF plus 5-Aza-CdR at $10^{-6} \mathrm{M}$ than in the culture containing GM-CSF alone after 3 days. Onefourth of the cells expressed myeloid markers irrespec- 
a
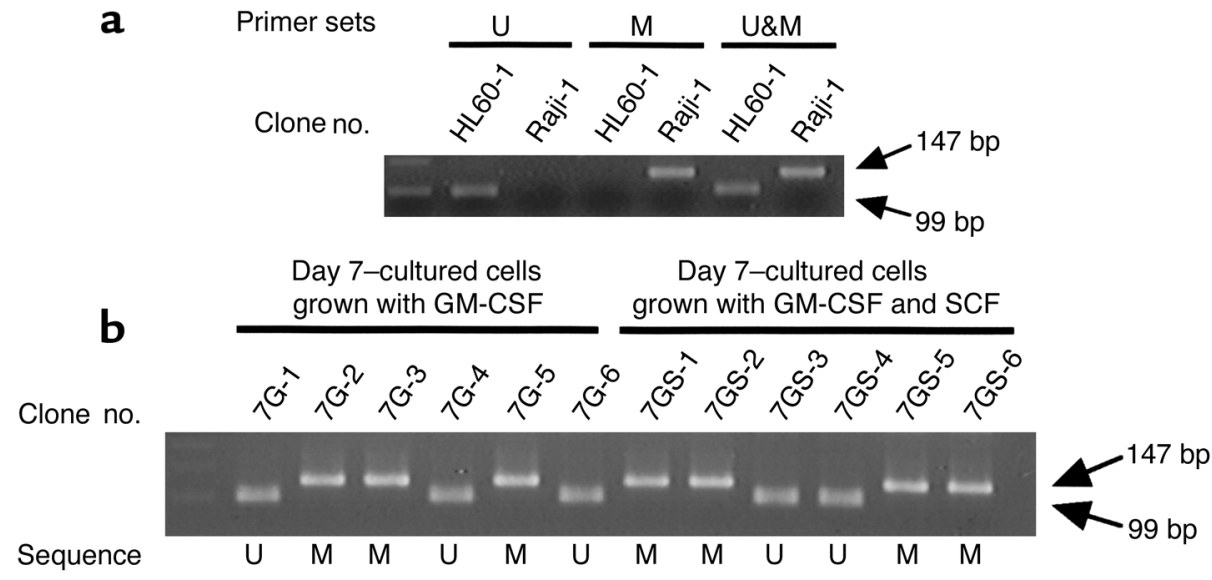

c Cultured cells grown with GM-CSF

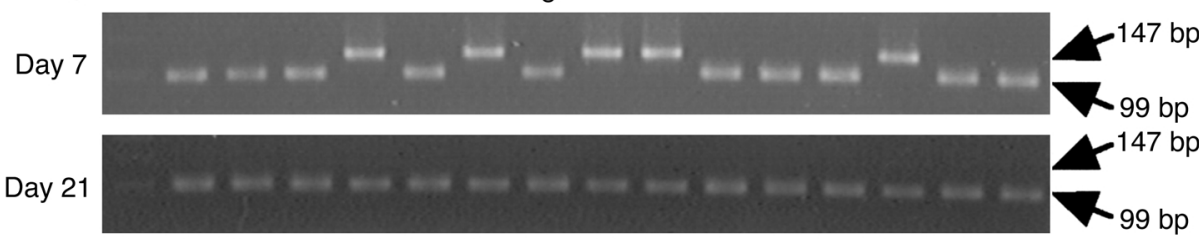

Cultured cells grown with GM-CSF + SCF

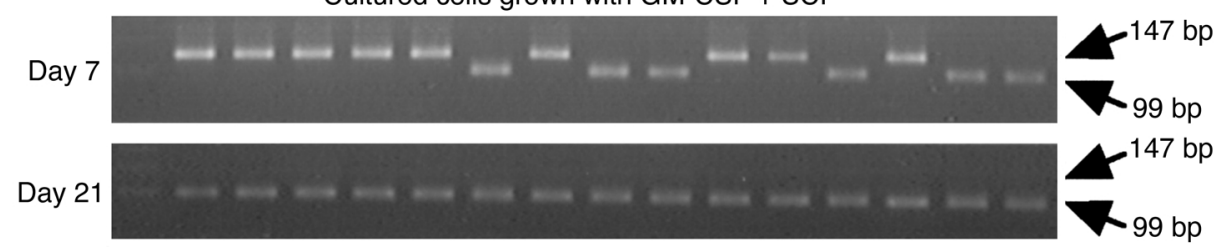

\section{Figure 6}

Detection of CpG island methylation in the $p 15$ gene by PCR analysis. To discriminate between methylated and unmethylated CpG island $(-12$ and +251 relative to the transcriptional starting site) of the p15 gene, we performed PCR analysis. The primers used are p15-MF, p15-MR, p15-UF, and p15-UR. (a) Comparison of PCR methods. $U$, p15-UF + p15-UR; M, p15-MF + p15-MR; U\&M, p15-UF + p15-UR $+p 15-M F+p 15-M R$. Numbers of clones from HL60 cells and Raji cells correspond to those of clones shown in Figure 4c. 99-bp products, unmethylated; 147-bp products, methylated. (b) Comparison of methylation status of 12 clones of the day 7-cultured cells generated by GM-CSF or GM-CSF + SCF between the PCR and sequencing method. Individual clones correspond to those shown in Figure 5a. (c) The PCR analysis for the methylation of the p15 CpG island in another 15 clones of the day 7 - or day 21-cultured cells. tive of treatment with 5-Aza-CdR. CD14-/CD15- cells were more immature than $\mathrm{CD} 14^{+} / \mathrm{CD} 15^{+}$cells, based on the expression of CD34 and CD33 (Table 3). In addition, $\mathrm{CD} 14^{-} / \mathrm{CD} 15^{-}$cells contributed to an initial increase in $\mathrm{p} 15 \mathrm{CpG}$ island methylation to a greater extent than did $\mathrm{CD} 14^{+} / \mathrm{CD} 15^{+}$cells. When day 20 -cultured cells grown with GM-CSF from cord blood CD $34^{+}$ cells or HL60 cells were target cells, the exposure to 5-Aza-CdR at $10^{-6} \mathrm{M}$ for 3 days did not influence the production of progeny (data not shown).

To elucidate whether the methylated cells had a growth advantage, we examined the correlation of the size to the methylation status of GM colonies. On day 10 , ten GM colonies grown with GM-CSF + SCF from cord blood $\mathrm{CD}^{2} 4^{+}$cells were individually picked up and then divided into small GM colony groups and large colony groups. Small GM colonies were defined as those consisting of fewer than 1,000 constituent cells (594 \pm 283 cells, $n=5)$ and large colonies as those consisting of more than 2,000 constituent cells $(2,936 \pm 1,277$ cells, $n=5)$. The incidence of $p 15 \mathrm{CpG}$ island methylation was significantly greater in large GM colonies $(86 \% \pm 5 \%)$ than in small colonies $(54 \% \pm 8 \%)$.

\section{Discussion}

It has been demonstrated that the transcriptional repression of $p 15$ due to cytosine methylation of the $\mathrm{CPG}$ island region occurs in several types of hemato- logical malignancies, including AML and MDS (7-9). In peripheral blood MNCs of normal individuals, the p15 CpG island was initially reported to be unmethylated as determined by Southern blot analysis and PCR analysis based on restriction enzyme reaction cleavage (8). On the other hand, bisulfite genomic sequencing showed that lymphocytes of normal subjects are methylated at some CpG sites in most alleles $(24,25)$. This discrepancy between the two different approaches may be accounted for by an ability or an inability to assess the methylation status of each CpG site within individual alleles. Therefore, we used the latter technique in the present study. On stimulation with GMCSF or GM-CSF + SCF, a two-phase methylation at the $5^{\prime} \mathrm{CpG}$ island in exon 1 of the $p 15$ gene was observed during the differentiation of both cord blood and bone marrow $\mathrm{CD}_{3}{ }^{+}$cells into granulocytes and macrophages. Similar methylation emerged in the $p 15$ promoter region in the culture with cord blood CD34 ${ }^{+}$ cells and GM-CSF. By contrast, the $p 16$ promoter region was entirely unmethylated in cord blood $\mathrm{CD} 34^{+}$ cells and day 7-cultured cells grown with GM-CSF or GM-CSF + SCF (data not shown). These results suggest a close link between $p 15 \mathrm{CpG}$ island methylation and the cytokine-dependent myeloid development from normal hematopoietic progenitors.

In cord blood $\mathrm{CD} 34^{+}$cells cultured with GM-CSF or GM-CSF + SCF, the percentage of the alleles with 


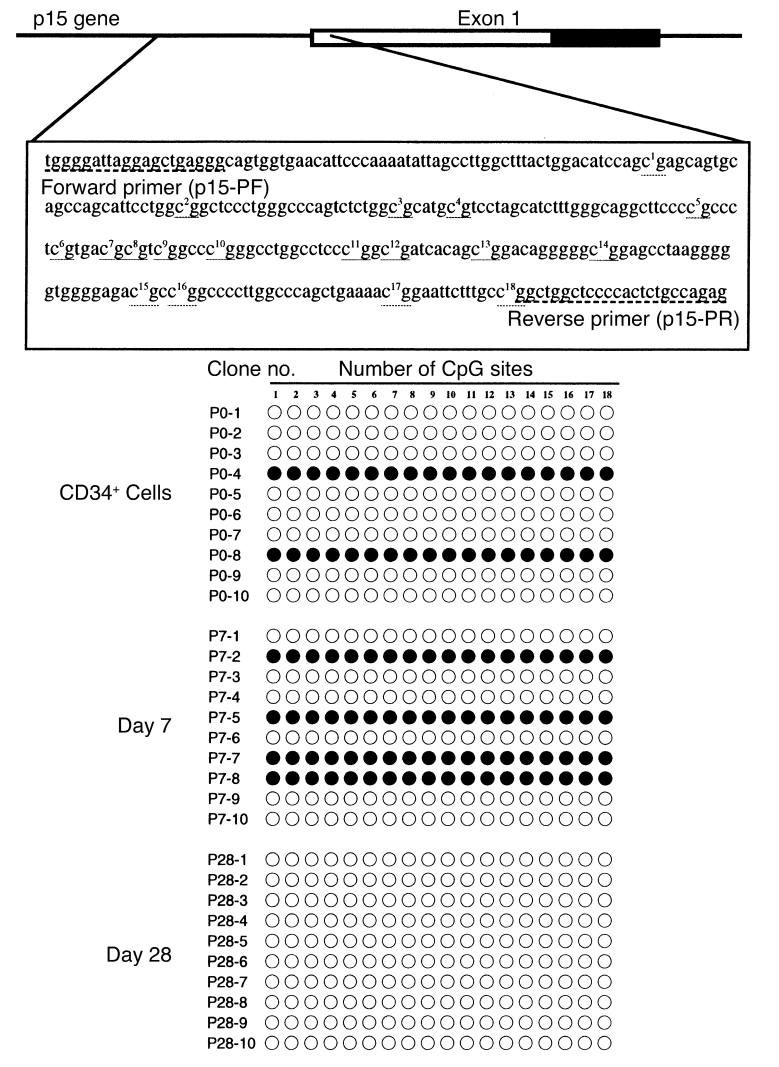

Figure 7

Methylation status of the $p 15$ promoter region during GM-CSF-dependent myeloid development from cord blood CD34+ cells. We examined the allelic methylation status of CPG sites in the promoter region of the $p 15$ gene, using bisulfite genomic sequencing. Ten clones were randomly selected and sequenced at each time point. Each row of circles corresponds to one clone. Methylated CpG sites are marked as filled circles and unmethylated sites as open circles. All of the CPG sites between position -285 and +12 relative to the transcriptional point stand in a line. The binding sites of the primers used in this experiment are also shown (p15-PF and p15-PR).

methylated $p 15 \mathrm{CpG}$ islands increased to approximately $50 \%$ to $60 \%$ until day 7 , compared with the level obtained at the beginning of culture, after which the percentage declined. On the other hand, the intracellular p15 content of the cultured cells was at negligible or low level up to day 14 , but subsequently increased, according to the flow cytometric analysis and Western blot analysis. Treatment of day 5-cultured cells with 5-Aza-CdR at $10^{-6} \mathrm{M}$ for 3 days abrogated the ability of GM-CSF to increase the allelic methylation and caused a significant increment in the p15 expression. The mean number of total viable cells was substantially lower in the culture containing GM-CSF plus 5-Aza$\mathrm{CdR}$ at $10^{-6} \mathrm{M}$ than in the culture containing GM-CSF alone. However, no significant difference was found in the percentages of $\mathrm{CD} 14^{+} / \mathrm{CD} 15^{+}$cells between the two groups. These results imply that methylation of the $p 15$ $\mathrm{CPG}$ island regulates negatively the p15 expression, and that the transcriptional silencing of $\mathrm{p} 15$ functions as a stimulator for the proliferation rather than differentiation of myeloid lineage cells. Nevertheless, we can- not rule out the involvement of genes other than the p15 gene whose expressions are regulated by promoter DNA methylation in this differentiation pathway.

It is generally held that the $p 15$ promoter region $\mathrm{CpG}$ island is not methylated in normal cells and that the presence of this change is a tumor-specific event associated with an aberrant transcriptional silencing of the involved gene and loss of gene function. In the current study, one-half of the early-appearing cultured cells grown from cord blood or bone marrow $\mathrm{CD}^{2} 4^{+}$cells under stimulation with GM-CSF or GM-CSF + SCF displayed homogeneous methylation at all of the $C P G$ sites in the region located between positions -12 and +251 relative to the transcriptional starting site of the $p 15$ gene. In addition, a small number of cord blood CD34 cells were methylated in the promoter region of the $p 15$ gene at the beginning of culture, whereas normal marrow $\mathrm{CD} 34^{+}$cells showed no signs of the CPG island methylation. It is well known that several circulating cytokines are elevated in the neonatal period and that cord blood hematopoietic progenitors exhibit higher proliferative potential in the presence of growth factors compared with marrow progenitors. Taken together, it is possible that endogenously produced hematopoietic factors bind to the surface of cord blood $\mathrm{CD} 34^{+}$cells in vivo and lead to methylation of the p $15 \mathrm{CpG}$ island. The cytokine stimulation may be able to induce $p 15$ promoter methylation in normal hematopoietic cells, although such methylation is absent in steady-state hematopoietic cells. Cameron et al. (25) demonstrated pronounced intra-allelic heterogeneity of methylation with varying degrees of methylation density at the $\mathrm{CpG}$ island within this region of the $p 15$ gene in primary acute leukemia, implying an apparent difference in the methylation pattern of the $\mathrm{p} 15$ gene between normal myelopoiesis and hematological malignancies. Considering the existence of hematopoietic progenitors harboring hypermethylated $p 15$ gene alleles, it is speculated that these cells can escape from negative growth regulatory signals ema-

\section{Table 3}

Surface marker expression and $p 15 \mathrm{CpG}$ island methylation status of day 8-cultured cells grown with GM-CSF and/or 5-Aza-CdR

\begin{tabular}{|c|c|c|c|c|}
\hline & \multicolumn{2}{|c|}{ CD14-/CD15- cells } & \multicolumn{2}{|c|}{ CD $14^{+} / \mathrm{CD} 15^{+}$cells } \\
\hline & GM-CSF & $\begin{array}{l}\text { GM-CSF + } \\
\text { 5-Aza-CdR }\end{array}$ & GM-CSF & $\begin{array}{l}\text { GM-CSF + } \\
\text { 5-Aza-CdR }\end{array}$ \\
\hline$\%$ of $\mathrm{CD}_{3} 3^{+}$cells & 12 & 10 & 54 & 56 \\
\hline$\%$ of CD $34^{+}$cells & 19 & 21 & 6 & 7 \\
\hline $\begin{array}{l}\% \text { of } p 15 \mathrm{CpG} \\
\text { island methylation }\end{array}$ & 52 & 20 & 20 & 0 \\
\hline
\end{tabular}

Expression of CD33 and CD34 on day 8-cultured cells (CD14-/CD15- cells and $\mathrm{CD} 14^{+} / \mathrm{CD} 15^{+}$cells) grown from cord blood $\mathrm{CD} 34^{+}$cells was evaluated by flow cytometry, using a combination of PE-conjugated anti-CD14 mAb, FITC-conjugated anti-CD15 mAb, and PC5-conjugated anti-CD33 or CD34 $\mathrm{mAb}$. The percentages of alleles with methylated $p 15 \mathrm{CpG}$ islands were determined by the PCR analysis in 25 alleles derived from CD14-/CD15- cells and $\mathrm{CD} 14^{+} / \mathrm{CD} 15^{+}$cells sorted by flow cytometry. $5-$ Aza-CdR was used at $10^{-6} \mathrm{M}$. 
nating from $\mathrm{p} 15$, resulting in a proliferative advantage, and perhaps transform into a leukemic clone if combined with other defect(s).

In the mouse, most genes are subject to a process of active demethylation starting promptly after fertilization. Such genome-wide demethylation is followed by programmed de novo methylation. Gene-specific demethylations then form a terminal methylation pattern that is clonally inherited in the soma (27). The present findings suggest that a dynamic DNA methylation change is involved in the expression of the tissuespecific gene during human myeloid development as well as in murine embryo development.

\section{Acknowledgments}

We are deeply indebted to A. Komiyama (Department of Pediatrics, Shinshu University School of Medicine) for helpful comments. We also thank Y. Fukushima (Department of Clinical and Molecular Genetics, Shinshu University School of Medicine) for the helpful advice and S. Ito (Blood Transfusion Service, Shinshu University Hospital) for excellent technical assistance. This work was supported by Grants-in Aid numbers 11670753 and 09041178 from the Ministry of Education of Japan.

1. Lois, A.F., Cooper, L.T., Geng, Y., Nobori, T., and Carson, D. 1995 Expression of the p16 and p15 cyclin-dependent kinase inhibitors in lymphocyte activation and neuronal differentiation. Cancer Res. 55:4010-4013.

2. Schwaller, J., et al. 1997. Expression and regulation of G1 cell-cycle inhibitors (p16INK4A, p15INK4B, p18INK4C, p19INK4D) in human acute myeloid leukemia and normal myeloid cells. Leukemia. 11:54-63.

3. Hannon, G.J., and Beach, D. 1994. p15INK4B is a potential effector of TGF-beta-induced cell cycle arrest. Nature. 371:257-261.

4. Serrano, M., Hannon, G.J., and Beach, D. 1993. A new regulatory motif in cell-cycle control causing specific inhibition of cyclin D/CDK4. Nature. 366:704-707.

5. Kubota, T., et al. 1997. Methylation-specific PCR simplifies imprinting analysis. Nat. Genet. 16:16-17.

6. Singal, R., and Ginder, D.G. 1999. DNA methylation. Blood. 93:4059-4070.

7. Herman, J.G., Jen, J., Merlo, A., and Baylin, S.B. 1996. Hypermethylationassociated inactivation indicates a tumor suppressor role for $\mathrm{p} 15 \mathrm{INK} 4 \mathrm{~B}$ Cancer Res. 56:722-727.

8. Uchida, T., et al. 1997. Hypermethylation of the p15INK4B gene in myelodysplastic syndromes. Blood. 90:1403-1409.
9. Quesnel, B., et al. 1998. Methylation of the p15(INK4b) gene in myelodysplastic syndromes is frequent and acquired during disease progression. Blood. 91:2985-2990.

10. Sawai, N., et al. 1999. Neutrophilic cell production by combination of stem cell factor and thrombopoietin from $\mathrm{CD} 34^{+}$cord blood cells in long-term serum-deprived liquid culture. Blood. 93:509-518.

11. Sawai, N., et al. 1999. Thrombopoietin augments stem cell factordependent growth of human mast cells from bone marrow multipotential hematopoietic progenitors. Blood. 93:3703-3712.

12. Kinoshita, T., et al. 2000. Retinoic acid is a negative regulator for the differentiation of cord blood-derived human mast cell progenitors. Blood. 95:2821-2828.

13. Sawai, N., Koike, K., Higuchi, T., Ogami, K., and Oda, M. 1998. Thrombopoietin enhances the production of myeloid cells, but not megakaryoocytes, in juvenile chronic myelogenous leukemia. Blood. 91:4065-4073.

14. Higuchi, T., Koike, K., Sawai, N., and Koike, T. 1997. Proliferative and differentiative potential of thrombopoietin-responsive precursors: expression of megakaryocytic and erythroid lineages. Exp. Hematol. 25:463-470.

15. Higuchi, T., et al. 1997. Megakaryocytes derived from CD34-positive cord blood cells produce interleukin-8. Br. J. Haematol. 99:509-516.

16. Zupo, S., et al. 1996. CD38 expression distinguishes two groups of B-cell chronic lymphocytic leukemias with different responses to anti-IgM antibodies and propensity to apoptosis. Blood. 88:1365-1374.

17. Sawai, N., et al. 1999. Apoptosis of erythroid precursors under stimulation with thrombopoietin: contribution to megakaryocytic lineage choice. Stem Cells. 17:45-53.

18. Ma, F., et al. 1998. Establishment of a GM-CSF-dependent megakaryoblastic cell line with the potential to differentiate into an eosinophilic lineage in response to retinoic acids. Br. J. Haematol. 100:427-435.

19. Kamijo, T., et al. 1997. Analysis of synergism between stem cell factor and granulocyte-macrophage colony-stimulating factor on human megakaryoblastic cells: an increase in tyrosine phosphorylation of 145 $\mathrm{kDa}$ subunit of c-kit in two-factor combination. Leuk. Res. 21:1097-1106.

20. Wong, D.J., Foster, S.A., Galloway, D.A., and Reid, B.J. 1999. Progressive region-specific de novo methylation of the $\mathrm{p} 16 \mathrm{CpG}$ island in primary human mammary epithelial cell strains during escape from $\mathrm{M}(0)$ growth arrest. Mol. Cell. Biol. 19:5642-5651.

21. Gonzalgo, M.L., and Jones, P.A. 1997. Rapid quantitation of methylation differences at specific sites using methylation-sensitive single nucleotide primer extension (Ms-SNuPE). Nucleic Acids Res. 25:2529-2531.

22. Drexler, H.G. 1998. Review of alterations of the cyclin-dependent kinase inhibitor INK4 family genes p15, p16, p18 and p19 in human leukemialymphoma cells. Leukemia. 12:845-859.

23. Herman, J.G., Graff, J.R., Myohanen, S., Nelkin, B.D., and Baylin, S.B. 1996. Methylation-specific PCR: a novel PCR assay for methylation status of CpG islands. Proc. Natl. Acad. Sci. USA. 93:9821-9826.

24. Aggerholm, A., Guldberg, P., Hokland, M., and Hokland, P. 1999. Extensive intra- and interindividual heterogeneity of $\mathrm{P} 15 \mathrm{INK} 4 \mathrm{~B}$ methylation in acute myeloid leukemia. Cancer Res. 59:436-441.

25. Cameron, E.E., Baylin, S.B., and Herman, J.G. 1999. p15(INK4B) CpG island methylation in primary acute leukemia is heterogeneous and suggests density as a critical factor for transcriptional silencing. Blood. 94:2445-2451.

26. Herman, J.G., et al. 1997. Distinct patterns of inactivation of p15INK4B and p16INK4A characterize the major types of hematological malignancies. Cancer Res. 57:837-841.

27. Razin, A., and Shemer, R. 1995. DNA methylation in early development. Hum. Mol. Genet. 4:1751-1755. 